\title{
Local perceptions, attitudes, beliefs, and practices toward bird-window collisions in Monteverde, Costa Rica
}

\author{
Rose Marie Menacho-Odio \\ Programa de Manejo de Recursos Naturales, Escuela de Ciencias Exactas y Naturales. Universidad Estatal a Distancia. 474-2050, San José, \\ Costa Rica; rmenacho@uned.ac.cr
}

Received 03-X-2017 • Corrected 03-XII-2017 • Accepted 08-XII-2017

\begin{abstract}
Bird-window collisions are an important cause of bird mortality worldwide. Reducing collisions requires understanding of the costs and benefits perceived by stakeholders. I consulted two focus groups, conducted 18-semi-strcutured interviews and applied surveys to 58 residents of Monteverde, Costa Rica, to understand their perception of the problem. Many reported collisions in their houses but there is a lack of information about the magnitude of the situation. Black silhouettes are the most frequent method of prevention, even though they are mostly ineffective. The main factors for selecting methods include unblocked views, aesthetics, effectiveness, ease of installation and removal, and ease of maintenance. The preferred effective method was cords (Acopian Bird Savers), and painted dots was the least liked. I recommend education about effective methods for Monteverde and similar communities.
\end{abstract}

Key words: bird-building collisions, methods to prevent collisions, bird mortality, Green building design, bird-friendly buildings.
RESUMEN: Percepciones locales, actitudes, creencias y prácticas sobre colisiones de aves en ventanas en Monteverde, Costa Rica. Las colisiones de aves con ventanas son una causa importante de mortalidad de aves en todo el mundo. La reducción de colisiones requiere la comprensión de los costos y beneficios percibidos por los tomadores de decisiones. Consulté dos grupos focales, realicé 18 entrevistas semi-estructuradas y apliqué encuestas a 58 residentes de Monteverde, Costa Rica, para comprender su percepción del problema. Muchos reportaron colisiones en sus casas, pero hay una falta de información sobre la magnitud de la situación. Las siluetas oscuras de aves son el método más frecuente de prevención, aunque en su mayoría son ineficaces. Los factores principales para seleccionar métodos incluyen que no bloqueen la vista, estética, efectividad, facilidad de instalación y eliminación, y facilidad de mantenimiento. El método preferido son las cuerdas colgantes (Acopian Bird Savers), y los puntos pintados eran los menos apreciados. Recomiendo educación sobre métodos efectivos para Monteverde y comunidades similares.

Palabras claves: colisiones aves-edificios, métodos para prevenir colisiones, mortalidad de aves, diseño de edificios verdes, edificios amigables con las aves.
Bird-window collisions are a major cause of mortality of birds worldwide (Klem, 2015). Each year, in the United States, up to one billion birds die from hitting windows (Klem, 1990b; Loss, Will, Loss \& Marra, 2014). Birds are unable to distinguish glass as an obstacle because they only can see a reflection of the surrounding habitat on the glass pane, or only see through the glass to what is on the other side of the window (Klem, 1989; 2014). The collision often causes an intracranial hemorrhage that can kill the bird after a short period of time (Klem, 1990a).

In Costa Rica, the first study of bird-window collisions was conducted by Graham (1997). His study showed that bird-window collisions may be an important source of mortality for hummingbirds in La Selva, Sarapiquí, particularly hermit hummingbirds. In 2015, Menacho-Odio registered 131 species in Costa Rica that collided with windows or 14\% of the country's 918 bird species. In 2000, Young and McDonald (2014) warned that hundreds of birds die in the forested areas of the Monteverde, Costa Rica, after striking windows. These and other studies urge the need to implement measures that can protect birds from such collisions.

The implementation of effective methods to reduce bird collisions will require active social participation. Snep et al. (2016) cited key stakeholders for urban bird conservation as urban planers, urban designers, architects, landscape architects, urban developers, homeowners, tenants, and educational and communication staff. However, before promoting pro-environmental behavior, such as the implementation of effective methods to prevent bird-window collisions, it is important to understand perceived social costs and benefits of such 
behavior. Individuals make reasoned choices and choose alternatives with highest benefits against lowest costs. They also have moral and normative concerns; and contextual factors and the habits of the stakeholders also influence behavior (Brant, 2000; Steg \& Vlek, 2009). This study endeavored to understand these factors among the residents of Monteverde, Costa Rica. The specific objectives of this research were to: 1 ) identify socio-economic and environmental factors that drive the installation of windows, 2) describe the perception that residents have of bird-window collisions as a threat to birds, 3) understand beliefs about why birds collide with windows, and 4) investigate knowledge of, attitudes about, and use of, different methods to prevent bird-window collisions by stakeholders.

\section{METHODS}

Study Area: The study was conducted in the Monteverde community, district of Monte Verde, located in the Tilarán Mountain Range $\left(10^{\circ} 18^{\prime} \mathrm{N}, 84^{\circ} 49^{\prime} \mathrm{O}\right)$, Puntarenas, Costa Rica, at 1 300-1 550m elevation. The rainy season occurs from May to December, with an average precipitation of $2485 \mathrm{~mm}$ /year. From December to April strong northeast trade winds carry humidity as mist (Wheelwright, 1984; Young, Garvin, \& McDonald, 1993). This study area includes two life zones: Premontane wet forest and Lower montane wet forest. Nature tourism is the main economic activity (Alleh, 2015). This community is located near the Monteverde Cloud Forest Reserve and other forest reserves that also receive tourists. Aura Sandí, Santa Elena Water Administrator, indicated that there are 158 residences in this zone (Pers. comm. August, 2017). Many houses are surrounded by pastures, gardens, and secondary forest.

Data collection: The study employed a mixed approach using quantitative and qualitative methods. The information was collected from August 2014 to September 2017.

\section{Qualitative methods}

Direct observation: From August 2014 to August 2017, I visited every month or every two months the Monteverde community, and I observed methods to prevent bird collisions that were used on windows. I photographed windows that used different methods.

Semi-structured interviews: From August 2014 to September 2017, I conducted 18 semi-structured interviews with biologists, architects, tourist managers, artists, naturalist guides, and other residents of the area. I selected the people using "the snow ball sampling" technique. Each interview was recorded and transcribed establishing categories using Nvivo.

Focus groups: On October 10, 2015, I invited a heterogeneous group of 12 inhabitants, including educators, a hotel manager, a naturalist guide, biologists, farmers, researchers, and conservationists to the Monteverde Institute. Then on July 27, 2017, I invited a homogenous group of hotel managers and staff; six people participated from different hotels in the Monte Verde district. In both focus groups we discussed bird-window collisions in the area, personal experiences, preventive methods that were known, and possible actions to implement at the community level to reduce mortality. Each activity was recorded and transcribed. The different commentaries were organized into categories.

\section{Quantitative methods}

Mini-surveys: From March 12 to October 20, 2015, I invited Monteverde community residents to four talks about my research project. These were held at the Monteverde Institute, Monteverde Cloud Forest Reserve, and the Monteverde Friends School. Before each talk I asked the participants to fill-out a short questionnaire about the importance of the problem of bird-window collisions, and asked why this could be a problem.

Exhibition of bird-window collision prevention methods: On September 21, 2015, with the help of several residents, I installed a display of different prevention methods in the Monteverde Institute library. Each display window had, next to it, a card explaining the name of the method, the materials used, and cost. The methods exhibited were: vertical cords (Acopian Bird Savers); dots of $2 \mathrm{~mm}$ at $4 \mathrm{~cm}$ of distance, white and rainbow colors; and vertical lines of $3-4 \mathrm{~mm}$ at $10 \mathrm{~cm}$ from each other; adhesive tape of light blue color in vertical strips separated by $10 \mathrm{~cm}$ from each other; an individual black silhouette of a bird, stickers of butterflies, a "Window Alert Leaf Medley Decal"; and an adhesive decorative film "Magnolia Window Film" $(61 \times 91 \mathrm{~cm})$. On October 20, before the heterogeneous focus group, I asked the participants to fill-out a questionnaire asking how much they liked each method on a scale of 1 to 5 (Likert Scale), and to describe what they liked and what they did not like about each method.

Monteverde community survey: From 18 to 22 February, 2016, two volunteers and the main researcher (RMM) carried out a survey of Monteverde homes 
(Questionnaire in Digital Appendix). The objective population were residents 15 years or older. We excluded from the sample business and educational centers. One questionnaire was completed per house. I used sampling on geographic conglomerates, with seven conglomerates of 14-27 houses (average 21). We dedicated an entire morning or afternoon to each conglomerate and tried to reach as many houses as possible. The objective of the survey was to obtain information about the perceptions that the Monteverde community inhabitants have about the bird-window collisions problem, and their use of, and knowledge about, methods to prevent bird deaths. The questionnaire was designed with: a) a section to determine perception and knowledge of the problem; and b) methods known and used to prevent collisions. We also showed images of four effective methods: mesh, vertical cords, painted lines, and painted dots (Klem \& Saenger, 2013; American Bird Conservancy, 2016). We asked which method was most and least preferred, and why. Additionally, we inquired about socio-demographic aspects, such as length of residence in Monteverde, age, sex, nationality, level of studies, and occupation (Digital Appendix). The recorded interviews and focus groups were transcribed and organized by categories using Nvivo and according to the research objectives. The survey answers were translated to an Excel database. Frequencies of answers were obtained using dynamic tables.

\section{RESULTS}

Demographics Summary: We visited a total of 73 houses (an average of 10 houses per conglomerate). Fifty-eight householders completed the surveys and we had a non-response in fifteen houses (20.5\%). For this sample, the maximum error is $8,5 \%$ and a confidence level of $90 \%$. Fifty-eight inhabitants responded to the survey (male $52 \%$, female $48 \%$ ). Forty-three $(52 \%)$ were 35 years or older; thirty-four (59\%) had university studies; 13 (22\%) high school studies, and 11 (19\%) primary school studies. Thirty (52\%) had Costa Rican nationality, 16 (28\%) had United States nationally, and nine (16\%) had another nationality (Canadian, Nicaraguan, Australian, British, and Chilean). Thirty-six (62\%) had lived less than 30 years in Monteverde, and 22 (37\%) had lived more than 30 years in the area. Sixteen persons indicated that they worked, or previously worked, as educators, 11 worked as naturalist guides, and 10 were biologists or natural resources managers. Other occupations mentioned were hotel staff, artists, research assistants, farmers, merchants, kindergarten assistant, religious workers, and students.

\section{Environmental and Socio-economic drivers of ur-} ban growth and window installations in Monteverde: During decades, the growing number of tourists per year has favored the urbanization of Monteverde and has increased the demand and number of luxury hotels, restaurants, and entertainment venues (Cartín \& Ludwig, 1985; Davis, 2009; Burlingame, 2014; G. Vargas, Life Coordinator, pers. comm. August 23, 2017). There is no regulatory plan in Monteverde. This lack of legal regulations allows the establishment of buildings with large panes of glass in forested areas (G. McAdam, pers. comm., October 14, 2015). The Sustainable Tourism Certification, following green building design principles (Kenney, 2015) promotes the use of big panes of glass to allow the entrance of light and natural ventilation in order to reduce energy costs (ICT, 2017).

According to local residents, windows provide a series of benefits in relation to the Monteverde climate conditions and to landscape enjoyment. Rain, wind, and humidity are relevant environmental factors especially when houses are surrounded by forest because their interior can be very humid. Windows allow the entrance of natural light desirable to reduce humidity. Despite the relevance of the climate, one of the most important aspects of house design is the view. The inhabitants of Monteverde want to enjoy the landscape, either the distant view of the Gulf of Nicoya in the Pacific Ocean, or the nearby mountains. "Many people say that they want to feel as if they were part of the out-of-doors. What are the implications? Well, lots of windows, lots of light and, obviously large windows that don't block the view" (G. McAdam, pers. comm., October 14, 2015). A hotel manager explained the importance of the view for visitors. "We use the glass as a way to create visible spaces so that people can enjoy the garden. In that way, they get out of the routine of the cities and their surroundings, and they come to more natural settings".

Perception of bird-window collisions as a threat to birds: To the question, "Which, do you think, are the main threats to birdlife in Monteverde?" a total of 109 answers were given by the 58 people surveyed. Most of them referred to climate change $(n=29)$. Habitat loss and bird-window collisions received the same number of answers $(n=16)$, followed by predation by domestic cats $(n=10)$. They also mentioned urbanization, invasive species, lack of food, hunting, feeders, dog predation, and pollution, among others. Then, we asked: “Do you consider that birds hitting windows is an important issue in Monteverde?" Forty-two (72\%) answered "Yes" and $10(17 \%)$ "No". A total of 94 reasons explaining whether 
bird-window collisions is considered an important issue in Monteverde were gathered. The reasons were classified into nine categories: Number of individuals and species of birds affected (35\%); lack of information and ignorance about the problem (15\%); moral reasons (13\%); infrastructure characteristics and factors that favor collisions (10\%); impact on bird populations and ecosystems (9\%); bird-window collisions increases other issues that also affect birds (9\%); affection of bird-window collisions on threatened and endangered species (6\%); Monteverde as a place where biodiversity and infrastructure coexist, and where a high number of environmentally conscious people live (3\%); and because birds are relevant for the tourism industry (1\%).

At the heterogeneous focus group, one hotel manager pointed out that for him, bird-window collisions clearly are a problem, because when collisions happen in front of the tourists, their reactions are negative, since it is opposite to the environmentally friendly image that the hotel promotes. A resident that has lived 25 years in Monteverde said that for a person that is not at home all the time, seeing three or four strike victims a year does not seem like a lot. People can live many years in the same place without perceiving that this is a big problem, because they actually see very little of it.

Beliefs about why birds hit windows: Some of the factors stated to explain why birds hit windows mentioned in the interviews were high windows $(n=5)$, many windows $(n=2)$, windows located in a North-South direction $(n=1)$, windows that don't have a roof over them, and strong winds $(n=1)$. It also was said that birds don't hit small windows. People said there are sections of buildings that are especially dangerous because birds are attracted to them, for example, those that have open interiors with skylights. Reflection on windows was often mentioned in the survey $(n=10)$, interviews, and focus groups: "In houses where there are no skylights and the interior is dark, a 'mirror' effect is created."; "Birds hit windows because they see the forest reflected. They see where they are going and fly really fast".

Knowledge and use of methods to prevent bird-window collisions in Monteverde: Since I started visiting the area, in August 2014, I have observed many windows with bird silhouettes (mostly black color), of different shapes and sizes in Monteverde, Cerro Plano, and Santa Elena (Fig. 1 in Digital Appendix). Those silhouettes were observed mostly on windows in hotels, restaurants, coffee shops, educational centers, and, not as often, houses. In some cases, the silhouettes were located at sight level $(1.5 \mathrm{~m})$, rather than on high windows. In 2002-2003, Roberto Wesson, artist, alarmed because of lack of actions to prevent birds' deaths, designed a color image of a hawk, hoping that more people would use it to prevent collisions (Fig. 2 in Digital Appendix). He indicated that "some important aspects of the silhouette are the barred pattern and the larger than usual eyes. The big eyes make it appear more menacing to other birds. Since it is covered with plastic it is possible to locate it outside of the window with scotch tape" (R. Wesson, pers. comm. August 25, 2015). Then he wrote in a local newspaper Aguapura, about the problem and presented the silhouette as a possible solution. At the library of the Monteverde Institute I found a research project by Hong (2006), a student, who tested silhouettes with eyespots and concluded that birds see and avoid them. A biologist commented that he used to leave dusty windows in his house to prevent collisions. Another family, in 2014, put a green, thick mesh on their house windows to stop collisions. Also, I observed pendants on windows in a conservationist institution and in some houses. Roberto Wesson used angled windows which he found effective to prevent collisions.

During the community survey we asked: "What methods to prevent bird window collisions do you know?" I listed the number of times a method was mentioned. In total, 13 methods were mentioned. Forty-two (72,4\%) of the surveyed people indicated bird silhouettes and stickers, followed by pendants $(n=18,31 \%)$, and in third place, mesh ( $n=16,27,6 \%)$. Other methods mentioned were curtains, cords, drawings, vertical lines, patterns, painted images, dots, dirty windows, plants, and bars (Fig. 3 in Digital Appendix). Then we asked: "Have you used any of those methods at home?" Most people, 31 (53\%), answered "no", while 25 (43\%) said "yes". Two people did not answer. When we asked what methods they had applied, most people said silhouettes or stickers $(n=12)$, pendants $(\mathrm{n}=6)$, and Curtains $(\mathrm{n}=4)$.

To the question: "Do you know any person in Monteverde that uses methods to prevent bird-window collisions?" Forty-nine (84\%) said "yes" and nine "no". When we asked to identify that person, they mentioned eight neighbors. One family was mentioned 10 times; the others once or twice. Most of the persons that were identified using methods to prevent collisions were biologists or conservationists, except one resident who started using cords as recommended by a biologist. They also named hotels $(n=6)$, the Monteverde Institute $(n=6)$, and the University of Georgia campus in San Luis $(n=1)$. When we asked: "What methods do these persons use?" they gave 52 responses. The methods used most often were: silhouettes $(n=24)$, mesh $(n=9)$, cords $(n=5)$, screen 
wire $(n=4)$, pendants $(n=3)$, drawings $(n=2)$, painted lines $(n=1)$, visible objects $(n=2)$, and paint $(n=1)$. During the survey we observed silhouettes in at least six houses. Two residents used mesh to prevent collisions and one used cords.

\section{Perceived effectiveness of known methods and preferred methods for preventing collisions: Although} silhouettes and stickers were the methods most often mentioned, $55 \%$ of those who mentioned them considered that they are of little use or only somewhat effective for preventing collisions. The perception of effectiveness was higher with mesh; $56 \%$ of those that know this method considered it effective to prevent collisions. The perception of effectiveness of curtains and cords was variable (Table 1 in Digital Appendix).

We showed images of four methods (cords, painted lines $10 \mathrm{~cm}$ apart from each other, mesh, and dots), and asked: "Which of these methods do you like the most and why?" The method most often mentioned was cords $(n=24)$, followed by mesh $(n=15)$, lines $(n=10)$, and dots $(n=1)$. We also asked: "What method you like least and why?" Twenty-three people indicated that dots was the method that they like least, followed by mesh-sieve $(n=19)$, painted lines $(n=8)$, and cords $(n=7)$.

Those that had visited the methods exhibition at the Monteverde Institute gave a higher score to cords $(\mathrm{Me}=3.7)$, followed by leaf-shaped stickers $(\mathrm{Me}=3.6)$, vertical lines $(\mathrm{Me}=3.2)$, bird silhouettes $(\mathrm{Me}=2,7)$, dots $(\mathrm{Me}=2,2)$, adhesive film $(\mathrm{Me}=2)$, and tape $(\mathrm{Me}=2)$.

I established categories for all the reasons given to explain why they most liked a method. The most common reason was "doesn't block the view", followed by "aesthetic" and "effectiveness" (Table 2 in Digital Appendix). On the other hand, when we categorized the answers to explain why they did not like a method, the most mentioned was "it blocks the view", followed by "it is not aesthetic" and "it is little or not effective" (Table 3 in Digital Appendix).

Cords: Householders that preferred cords as their favorite method $(n=19)$ explained their preference saying that cords don't block the view $(n=6)$, they are easy to put up and take down $(n=5)$ and easy to clean $(n=3)$, and they are effective because they move and they are natural. Those who had observed the exhibition of methods also pointed out that they don't distract or block the view as do other methods $(n=6)$, that they seem more effective because they move with the wind $(n=3)$, that they are aesthetic, easy to install, to repair, and allow for cleaning the window. Negative aspects about the vertical cords are that they look like bars $(n=3)$, that visibility is affected $(n=3)$, and that they could be expensive if it were necessary use them on many windows.

Mesh: People that liked the mesh said that it seems to be more effective $(n=5)$, does not block the view $(n=4)$, and allows the entrance of light $(n=2)$. Those that indicated the mesh as the least liked method said that it was intrusive, blocks the view $(n=7)$, aesthetically unpleasant $(n=6)$, difficult to clean and keep $(n=4)$, that birds would hit it and get hurt $(n=3)$, and that they feel like they are in an enclosure $(n=1)$.

Painted lines: Six persons preferred painted lines. They explained that they were aesthetic and decorative, easy to paint, easy to maintain, colorful, simple, less noisy, and more effective. During the exhibition survey they mentioned positive aspects such as easy to make, aesthetic, and allow for viewing outside $(n=3)$.

Painted dots: Only two people mentioned painted dots among the methods they liked most, explaining that it was worth trying and that they were effective. Nine persons said that this is the method they liked least because painted dots make people feel dizzy, are not effective, are unpleasant to see and are stressful, that they block the view, and look institutional. Those who participated in the exhibition also said that sight is directed to the dots instead of outside, that is, that they are distracting $(n=2)$, that they make one feel dizzy, and that they are not functional for preventing collisions.

\section{DISCUSSION}

Several factors that favored urban growth and window installation in Monteverde were identified in this study but some of them are not exclusive to this place. Since glass provides advantages such as transparency, weather protection, energy efficiency, is aesthetically appealing and allows landscape view enjoyment, the use of this material is considered sustainable and advantageous by modern architecture, and is spreading in many places around the world (Lewis, 2011; Kenney, 2015; DeWeerdt, 2016). The increasing installation of big panes of glass on buildings in forested areas of Monteverde should be considered a relevant issue because bird-window collision affects endangered and endemic species (Menacho-Odio, 2015), and also because vegetation that is close to the glass increases the danger of bird-window collisions for two reasons: first, because it attracts birds as a refuge, and second, because birds perceive images of vegetation reflected on the windows as if they were real (Kenney, 2015). Although tourism success is one the factors that has contributed to urban growth, nature tourism has also contribuited to forest regrowth 
and conservation of mature forest (Alleh, 2015). For this reason it is desirable to regulate urban growth and invest not only in green building design (DeWeerdt, 2016), but also in bird-friendly building designs that aim to reduce bird-window collision mortality (American Bird Conservancy, 2015). Finally, it would be desirable to include methods to reduce bird-window mortality and bird-friendly building criteria as part of the Sustainable Tourism Certification (ICT, 2017).

Many inhabitants of Monteverde already consider bird-window collisions a major threat to birds, but there is a lack of information about the magnitude of this situation in terms of number of individuals and species affected. Besides, residents are used to seeing just one or two dead birds during the year. An image of the accumulative number of the birds affected, and other images of the different species killed, could help them to understand the accumulative effect of this problem. The Fatal Light Awareness Program (FLAP) in Canada organizes an annual display of the nearly 2,000 birds that died after hitting windows in Toronto buildings. The activity is used to attract the public's attention and to provide information about the problem (FLAP, 2017; Bell, Mesure, \& Swaigen, 2017). Images of birds affected can be spread through newsletters of organizations like the Monteverde Institute, Monteverde Friends School, and others.

Individual black bird silhouettes are the most known and used method to prevent collisions in Monteverde. Klem (1990b) stated that owl and falcon silhouettes, and big eye patterns set individually or widely spaced, on or behind the glass panes, do not reduce significantly bird-window collisions. Effective methods include physical barriers and uniformly spaced elements, such as parachute cords, $3.2 \mathrm{~mm}$ wide, vertically arranged in front of the windows, nine centimeters distance one of the other; fritted glass showing visible patterns; micro-perforated vinyl; and feeders located less than $1 \mathrm{~m}$ from the glass surface. Window angling (20 to 40 degrees) reduces significantly the number of collisions compared with vertical panels (Klem et al., 2004). Monteverde inhabitants should be informed about methods that are effective (and which are not effective) for preventing collisions, but, even knowing what methods are effective, for Monteverde residents, there may be a conflict between the goal of enjoying nature and beautiful views, and the moral desire to conserve and protect birds, especially if the preventive methods proposed are effective, but block the view.

I found that many hotels and others touristic places exhibit silhouettes on their windows, which may be an indication of past collisions, but also show an interest in preventing future collisions. These tourism businesses have vested interests in the image of sustainability as many visitors seek businesses that are committed to the environment. This is a social pressure for taking actions that can favor the implementation of effective methods to prevent collisions in hotels, but it is important for hotel owners to make sure that visitors will approve of the methods that are applied. This can be easier if they understand that they are needed to reduce bird mortality.

A factor for determining the use of methods to prevent collisions is their observability. Observability is the degree to which the results of an innovation are visible to others (Rogers, 1983). Because of this, some proposed methods (such as mesh) are not considered to have the aesthetic qualities needed in order to be adopted by hotel owners and residents of the area. On the other hand, observability can be an advantage if a method is found to achieve desirable features such as not blocking the view, allowing sunlight entrance, and is effective. In this case, the social pressure to have an image of sustainablity can help to spread this method.

In this study I found that unblocked views, window aesthetics, ease of cleaning and maintaince, are characteristis desirable for Monteverde residents. Some of these criteria were found also by Oviedo and Menacho (2015). Silhouettes and stickers, the most known and used methods among the Monteverde residents surveyed, are attractive, do not block views, allow the entrance of light, are low cost, easy to make and install, and simple to maintain, but are not effective. The use of cords, lines, dots, mesh, and other methods that have the advantages that users want, such as unblocked views, aesthetics, entrance of light, and effectiveness, should be promoted.

Vertical cords have been proven effective by Klem and Saenger (2013), and it was also the method found most attractive by the Monteverde inhabitants surveyed. The option of keeping the cords attached to the low border of the window is relevante, because otherwise, with strong winds, they could hit the glass or walls, or become entangled. For any method, there is a need to study the effectiviness in Monteverde.

Bird-window collisions is a problem experienced by many inhabitants of Monteverde, but there is a lack of information about the magnitude of the problem and how to reduce the mortality. One way to let people see the magnitude is to show images of the different birds that have died after collisions. Another is to organize displays of corpses, like the FLAP display in Canada. Silhouettes are a known and used method despite their very low effectiveness. They have many advantages adapted to what people like, since they are cheap, easy 
to make, aesthetic, don't block views, and allow the entrance of light. It is important to communicate the low effectiveness of this method and to promote more effective methods like cords, painted dots, lines, and mesh, instead of silhouettes. Any solution that is promoted should consider that view, light entrance, and proven effectiveness, are important. Vertical cords were selected, among other methods, because they accomplish the criteria mentioned, although it is important to secure them tightly in order to avoid noise and tangling. Hotel and touristic places are under strong pressure to show an image of sustainability. Implementing methods to prevent collisions, especially if this becomes normative, responds positively to this pressure. It would be highly relevant to study the impact on tourism such measures would have. Even though the effectiveness of methods has been studied in the United States, it is relevant to study them in Costa Rica and other countries of the Neotropics, since the bird species and ecological conditions are different. Architects, engineers, and building industry professionals should be aware of this problem and about methods to prevent collisions because they are the ones responsable for designing buildings.

\section{ACKNOWLEDGMENTS}

I am grateful to Daniel Klem, Rosita Ulate, and Edgardo Arevalo for their valuable advice. DOCINADE professors also provided advice. Monteverde Institute, Monteverde Cloud Forest Reserve of the Tropical Science Center, Monteverde Biological Station, Hotel Poco a Poco, Hotel Belmar, and the Monteverde Friends School provided space and help during the study. To all the Monteverde residents, especially C. Acuña, L. G. McAdam, R. Wesson, G. Montero, J. and J. Stuckey, M. Wainwright, M. Rockwell, M. Díaz, M. Garro, B. and R. Guindon, R. Solano, G. Bello, G. Cisneros, M. Rockwell, S. L. Moreno, F. Joyce, K. Van Dusen, D. Hamilton, K. Master, S. Montiel, A. Gora, R. La Val, A. Pounds, and M. Tandy. A. Robledo and E. Navarro assisted with the survey. R. Chinchilla and B. Alvarez Garay helped with SIG and maps. R. and J. May provided useful inputs in the English usage of this manuscript.

\section{REFERENCES}

Alleh, K. E. (2015). Trade-offs in nature tourism: contrasting parcel-level decisions with landscape conservation planning. Ecology and Society, 20(1), 1-10.

American Bird Conservancy. (2015). Bird-Friendly Building Design. Retrieved from https://abcbirds.org/
wp-content/uploads/2015/04/Bird-friendly_Building_ Guide_WEB.pdf

American Bird Conservancy. (2016, mayo 11). Stop birding hitting windows. Retrieved from Effective window solutions for home owners and architects. Retrieved from https:// abcbirds.org/get-involved/bird-smart-glass/

Bell, A., Mesure, M., \& Swaigen, J. (2017, March 22). Ontario all squawk, no action on protecting migrating birds. Opinion. Retrieved from thestar.com: https://www. thestar.com/opinion/commentary/2017/03/22/ontario-all-squawk-no-action-on-protecting-migratingbirds-opinion.html

Brant, G. (2000). Voluntary and Regulatory Approaches: What is Necessary in Conservation Today? Washington, D.C.: United States Department of Agriculture.

Burlingame, L. (2014). Conservación en la región de Monteverde: contribuciones de las organizaciones conservacionistas. In N. T. Wheelwright, \& N. M. Nadkarni, Monteverde: ecología y conservación de un bosque nuboso tropical (pp. 546-622). Bowdoin's Scholars' Bookshelf. Book 3. Retrieved from http://digitalcommons.bowdoin.edu/ scholars-bookshelf/3/.

Cartín, N., \& Ludwig, E. (1985). Monteverde. Revista Geográfica de América Central (21-22), 199-203.

David, J. (2009). The Creation and Management of Protected Areas in. Monteverde, Costa Rica. Global Environment, 3, 96-119. Retrieved from http://www.environmentandsociety.org/sites/default/files/key_docs/davis_2009_3_0. pdf

DeWeerdt, S. (2016, March). When Green Buidlings are deadly to birds. Conservation Magazine Retrieved from http://www.conservationmagazine.org/2016/03/ green-buildings-deadly-to-birds/

FLAP. (2017, September 5). Rom and FLAP Annual Event. Retrieved from http://www.flap.org/

Graham, D. (1997). Spider webs and windows as potentially important sources of hummingbird mortality. Journal of Field Ornithology, 68(1), 98-101.

Hong, D. (2006). Preventing bird-window collisions: adding eyespots to falcon silhouettes. Monteverde, Costa Rica: EAP Tropical Biology Program, Costa Rica Spring.

ICT. (2017, September 4). Certificación para la sostenibilidad turística. Norma CST - Establecimientos de hospedaje. Retrieved from http://www.turismo-sostenible.co.cr/ pdf/Norma_CST_Hoteles_Costa_Rica.pdf

Kenney, D. (2015). Aesthetic Danger: How the Human Need for Light and Spacious Views Kills Birds and what we can (and should) do to fix this invisible hazard. Journal of Animal \& Natural Resource Law, XI, 137-160.

Klem, D. J. (1989). Bird-Window Collisions. Wilson Bulletin, 101(4), 606-620. 
Klem, D. J. (1990a). Bird injuries, cause of death, and recuperation from collisions with windows. Journal of Field Ornithology, 61(1), 115-119.

Klem, D. J. (1990b). Collisions between birds and windows: mortality and prevention. Journal of Field Ornithology, 61(1), 120-128.

Klem, D. J. (2014). Landscape, Legal, and Biodiversity Threats that Windows Pose to Birds: A review of an Important Conservation Issue. Land, 3(1), 351-361.

Klem, D. J. (2015). Bird-Window Collisions: A Critical Animal Welfare and Conservation Issue. Journal of Applied Animal Welfare Science, 18, S11-S17.

Klem, D. J., \& Saenger, P. (2013). Evaluating the Effectiveness of Select Visual Signals to Prevent Bird-window Collisions. The Wilson Journal of Ornithology, 125(2), 406-4011.

Klem, D. J., Keck, D., Marty, K., Miller, A., Ball, M., Niciu, E., \& Platt, C. (2004). Effects of window angling, feeder placement, and scavengers on avian mortality at plate glass. Wilson Bulletin, 116(1) 69-73.

Lewis, R. K. (2011, August 12). Modern architects are really in love with glass. The Washington Post. Retrieved from https://www.washingtonpost.com/realestate/modernarchitects-are-really-in-love-with-glass/2011/07/26/glQA7zY0AJ_story.html?utm_term=.b6c29ffb2938

Loss, S. R., Will, T., Loss, S., \& Marra, P. P. (2014). Bird-building coIlisions in the United States: Estimates of annual mortality and species vulnerability. The Condor, 116, 8-23.
Menacho-Odio, R. M. (2015). Colisión de aves contra ventanas en Costa Rica: conociendo el problema a partir de datos de museos, ciencia ciudadana y el aporte de biólogos. Zeledonia, 19(1), 10-21.

Oviedo, S., \& Menacho-Odio R. M. (2015). Actitud en la preferencia de métodos para evitar el choque de aves contra puertas y ventanas de vidrio en Costa Rica. Zeledonia 19(1): 22-31

Rogers, E. (1983). Diffusion of Innovations. New York: The Free Press.

Snep, R., Jip, L., Robert, K., Ruud, F., Holly, P., Monica, A., ... \& Yolanda, H. (2016). Urban bird conservation: presenting stakeholder-specific arguments for the development of bird-friendly cities. Urban Ecosystem, 19(4), 1535-1550. doi: 10.1007/s11252-015-0442-z

Steg, L., \& Vlek, C. (2009). Encouraging pro-environemtanll behaviour: An integrative review and research agenda. Journal of Environmental Psychology, 29, 309-317.

Wheelwright, N. T. (1984). Tropical Fruit-eating Birds and their Food Plants: A Survey of a Costa Rican Lower Forest. Biotropica, 16(3), 173-192.

Young, B. E., Garvin, M. C., \& McDonald, D. B. (1993). Blood parasites in birds from Monteverde, Costa Rica. Journal of Wildlife Diseases, 29(4), 550-560.

Young, B., \& McDonald, D. (2014). Aves. In N. T. Wheelwright, \& N. M. Nadkarni, Monteverde: Ecología y Conservación de un bosque tropical (pp. 266-303). Bowdoin's Scholars' Bookshelf. Book 3. Retrieved from http://digitalcommons.bowdoin.edu/scholars-bookshelf/3/.

See Digital Appendix at: / Ver Apéndice digital en: http://investiga.uned.ac.cr/revistas/index.php/cuadernos 